\title{
Dividend Policy and Market Performance of Listed Manufacturing Companies in Nigeria
}

\author{
Morrison E. Oniyama \\ Babcock University \\ Samuel Adebayo Olaoye \\ Babcock University \\ Grace O. Ogundajo \\ Babcock University
}

Interest in shareholders' value is gaining momentum as a result of several recent developments in the business environment. Basically, it is a critical decision and quite challenging for the managers to decide on an appropriate and ideal dividend policy to adopt, that will improve shareholders' wealth. In such decision dilemma, the managers are faced with the decision of whether to pay dividend or to plough back distributable earnings into the business. Therefore, this study examined the effect of dividend policy on shareholders' wealth. The result of the multiple regression analysis conducted revealed that dividend policy had significant effect on market price per share; dividend yield exerted significant negative effect on share price, dividend per share had significant positive effect on share price; while dividend pay-out ratio negatively but insignificantly influenced market share price. Managers should ensure that optimal decision is attained in the choice of the portion of distributable profits to be given as returns on shareholders' investment as this is germane in attaining its wealth maximization objective.

Keywords: shareholders' wealth, dividend yield, signaling, market price per share

\section{INTRODUCTION}

Globally, it is believed that maximization of profit is one of the crucial goals of the firm and to create wealth for the shareholders; this objective is considered more credible and critical to firms. The idea is that all residual earnings of a business belong to the legal owners of the company; shareholders' wealth becomes the ultimate goal of the firm. However, Sarwar (2013) posited that apart from the shareholders' wealth creation, there are also other contending stakeholders who are equally interested in the affairs of the company. From the investment perspective, the wealth of shareholders is considered as the discounting of expected future returns accrued to shareholders in the firm based on the invested principal (Chauhan, Ansari, Taqi \& Ajmal, 2019; Omoregie \& Eromosele, 2016).

Prior studies on shareholders' wealth creation specified that ensuring creation of shareholders' wealth is the only basic objective of the firm (Adediran \& Alade, 2013; Akit, et al., 2015). Contrarily, Akinsulire 
(2016) argued that shareholders are just a group among several stakeholders of the company. Other studies contented that dividend policy and payment of dividend to ensure shareholders wealth increase should not be the only priority of the firm (Biza-Khupe, 2016; Chenchene \& Mensah, 2015; Grant-Baker, 2016), pursing wealth maximization objective does not necessarily imply neglecting the other stakeholders' interest, for profit maximization sake. According to Grant-Baker (2016), the problems associated with shareholders 'wealth creation cannot be solved by dividend policy alone, or by payment of dividend but should have a relation to ensuring supply of quality goods at a reasonable price rate, maintain sound industrial relations, paying fair remuneration to employees, maintaining far recruitment practices and safe working condition, supporting other social responsibilities.

The benefits accrued to shareholders could be in form of capital appreciation or consistent periodic cash return on investments (Akit et al., 2015). The shareholders get the periodic cash returns on their investment in two ways, either as dividend or sales proceed from the disposal of their principal due to accumulated appreciation over time. The wealth shareholders' is measured as the volume of the investment in stock at the ruling market price. Shareholders' wealth of firms is characterized by the firm growth in sales, decision on nature of capital investment, profit margin improvement, and decision on the choice of capital mix (Ajanthan, 2013; Ojeme, Mamidu \& Ojo, 2015).

On the other part, the issue of dividend policy has been controversial and had sprang debates among scholars especially, its effect on shareholders' wealth over the years, while some are in support that dividend payment affects shareholders' wealth, others argue that it does not have any effect (Modigliani, Franco, Merton \& Hiller, 1958; Black \& Sholes, 1976; Barman-Joshi, 2011; Erasmus, 2012). Basically, it is a critical decision and quite challenging for the managers to decide on an appropriate and ideal dividend policy to adopt, that will improve shareholders' wealth. In such decision dilemma, the managers are faced with the decision of whether to pay dividend or to plough back distributable earnings into the business. However, when dividend payment decision is finally made, the management is yet faced with another critical and fundamental issue bordering on the following: when to pay and how much to be retained in the business for expansion repurposes, how much to be paid out to the shareholders as dividends (Biza-Khupe, 2016).

Several studies have been conducted on dividend policy both from the advanced economies and in the developing economies, yet the controversy is unsettled, example includes one of the first studies to discuss dividend policy (Gordon, 1956; Lintner (1956) who examined dividend policy in America in 1950s. Several studies have been carried out after the studies of Gordon and Lintner in 1956 till of recent time; still, arguments on the importance of dividend and dividend decision as part of management top decision remained a myth (Araoye \& Aruwaji, 2019, Baker, 2015; Monogbe-Tunde, 2015). However, one of the foremost studies in Nigeria on dividend policy include the study of Uzoaga and Alozie (1998), who studied the pattern of dividend policy pursued by Nigerian companies, particularly, considering the issue of indigenization and participation program as contained in the first indigenization Decree of 1973.

The problems associated with shareholders' wealth, are too far being resolved. For instance, the study of Ozuomba, Okaro and Okoye (2013) reported that dividend policy is less important in assessing the wealth of the firm shareholders while some other scholars claimed otherwise. The study of Rampershad and DeVilliers (2018) posited that if shareholders' wealth creation is the only essence of dividend policy, then, the company is already programmed to fail, rather the management should rather think in the direction of "stakeholders' wealth" rather than "shareholders' wealth" (Idewele \& Murad, 2019; Rampershad \& DeVilliers, 2018).

Over the years, the issue of dividend policy has been controversial and had sprang debates among scholars especially, its effect on shareholders' wealth, while some are in support that dividend payment affects shareholders' wealth, others argue that it does not have any effect (Black \& Sholes, 1976; BarmanJoshi, 2011; Erasmus, 2012; Modigliani et al., 1958). Basically, it is a critical decision and quite challenging for the managers to decide on an appropriate and ideal dividend policy to adopt, that will improve shareholders' wealth. In such decision dilemma, the managers are faced with the decision of whether to pay dividend or to plough back distributable earnings into the business. However, when dividend payment decision is finally made, the management is yet faced with another critical and fundamental issue bordering 
on the following: when to pay and how much to be retained in the business for expansion repurposes, how much to be paid out to the shareholders as dividends (Biza-Khupe, 2016).

Going by the conflicting results and divergence opinions on the effects of dividend policy on shareholders' wealth (Irtaz, Arslam \& Syed, 2018; Odesa \& Ekezie, 2015; Morara, 2015; Kibet, Tenai, Cheruiyot, Maru \& Kipsat, 2010; Priya \& Nimalathasan, 2013; Rafindadi \& Bello, 2019); there are still vast space to explore in this area hence the debate is yet unresolved. Hence, these justify the need to investigate the effect of dividend policy on shareholders from the Nigerian perspective. As a result, this study examined the effect of dividend policy on shareholders' wealth of the Nigerian listed manufacturing companies. Based on the set objective of this paper, it was hypothesized that:

Hypothesis: Market performance of Nigerian listed manufacturing firms is not significantly influenced by their dividend policy; and that return on asset does not significantly control the relationship between dividend policy and market performance of Nigerian listed manufacturing firms.

The rest of this paper is sectionalized as: section 2 dealing with the review of concept, theory and existing literature; in section 3, the methodology adopted is discussed while he results of the analysis carried out was captured in section 4, and section 5 depicts the conclusion and recommendations.

\section{REVIEW OF CONCEPTS, THEORETICAL BACKGROUND AND PRIOR STUDIES}

Under this section, the concepts used were reviewed, the underlying theory was discussed likewise the existing studies in relation to dividend policy and shareholders' wealth were examined.

\section{Review of Concepts}

Shareholders' Wealth

The concept of shareholders' wealth is considered one of the objectives of the firm. It is the reflection of the level financial performance of a company in term of the level of market worth. Grant-Baker (2016) stated that shareholders' wealth creation is one of the most important objectives of a company. Shareholders are the group of investors who are affected by effective and also ineffective utilization of the resources at the disposal of the management (Fernandez, 2015). The wealth of shareholder's is defined as the expected future returns accrued to the shareholders discounted at the ruling rate to its the present value. Market price per share is also called the intrinsic value of a share of stock or the actual value based on the actual variable taken from the firms accounting information (Nyor \& Nasiru, 2015). Nazrul (2019) provided that market value can be defined as the total naira value of all prominent shares of an organization, assessed through market capitalization and shareholders' equity. Market capitalization is derived by multiplying the current share price by the number of outstanding shares. The value from the capitalization is an index by market analysts to judge a corporate size, as; the index is the stock market along with other factors of market capitalization. Due to the fact that market capitalization is dependent on share price, it is not stable and moves erratically (Chaabouni, 2017); still, Liu (2018) argued that shareholder equity is a better reliable and accurate assessment of an organization's real net worth. According to Araoye and Aruwaji (2019), market share price is the total value investors are willing to pay or sell for one share of a company's stock or share. The study of Ebire, Sadiq and Onmonya (2019), maintained that the market share price takes into account both the company' current profitability and estimates of future profitability and reflects not just the value of the company's assets, rather an estimation of the company's ability optimally utilizes the assets to create value and earn profit on a sustainable basis.

\section{Dividend Policy}

This seek to clarify the proportion as how much of an establishment's earnings should be made available to shareholders in form of cash payment and how much should be retained by the establishment for other investment and/ or expansion purposes (Ebire, et al., 2019; Sijol \& Basit, 2016). Omoregie and Eromosele (2016) opined that it is dividend payment that determines the value of a firm, while (Kolawole, Sadiq \& Lucky, 2018; Ozuomba, et al., 2013) posited that the effect of dividend policy on shareholders wealth is important to investors who plan their portfolios based on dividend policies of companies, since it 
is the optimal dividend policy that can maximize the company's share price which ultimately lead to maximization of shareholders wealth. Some scholars believe that dividend policies are irrelevant in determining the wealth of shareholders while others argue that dividend policies are relevant and greatly influence the wealth of shareholders (Idewele \& Murad, 2019; Ozuomba, et al., 2013).

Several measures have been adopted in literature for dividend policy; this study employed three variables of dividend policy: dividend payout ratio (DPR), dividend yield ratio (DYR) and dividend per share (DPS) as used in the studies of Abu and Adebayo (2020), Aribaba, Ahmodu, Ogbeide, and Olaleye (2017), Ubesie, Emejulu, and Iyidiobi (2020), and Wajid, Arshad, Nazim, Bakhtiar and Qureshi (2014)

The dividend payout ratio is one of the financial ratios that measure the proportion of the current period earnings (profit) that is paid or distributed by the company to its shareholders inform of dividends (Akinleye and Ademiloye, 2018). The study of Idewele and Murad (2019) in defining dividend yield ratio related to the price-earnings ratio (P/E Ratio) as the ratio for assigning a value for a firm that measures its current share price relative to its per-share earnings. Irtaz et al., (2018)) opined that high dividend-yield is linked to a long term and positive abnormal return. Furthermore, Rampershad and DeVilliers (2018) posited that dividend yield is an estimate of the dividend-only return of a stock investment. The concept of dividend per share is one financial ratio to measure the amount of current dividend attributable to unit of ordinary shares in issue in a company. In this regard, dividend per share shows the actual returns that will be received or was received by the ordinary shareholders on a unit of shares (Akinleye \& Ademiloye, 2018; Okwuosa, 2005). This is considered a good measure of shareholders' wealth since it equally, measure the level of wealth created by the company for the benefit of the shareholders. Sani (2014) believed that the best dividend regulation is the policy that optimizes the stock price which pilot to shareholders' wealth maximization and ensures greater and swift financial growth. This study adopted the measure of dividend per share as used by Okwuosa (2005) and measured dividend per share (DPS) as follows: Ordinary share dividend divided by number of ordinary shares ranking for dividend.

One of the purpose financial ratios is to measure firm performance in term of the company's economic return based on asset utilization (Eliwa, 2015). Return on asset measures the profit for the period with the total assets employed by the entity in generating the profit during the same period (Irtaz et al., 2018). That is, it measures the amount of return earned on every $\mathrm{N} 1$ invested on assets. It helps shareholders determine the level of efficiency of the manager in the usage of the company's assets (Odesa \& Ekezie, 2015). Also return on assets (ROA) is a financial ratio used to measure the degree to which the assets have been used to generate profits (Nyor \& Nasiru, 2015; Ojeme et al., 2015). This study measured return on asset as: Return on assets $=$ Net profit before interest and tax $/$ Total Assets $\times 100$

\section{Underlying Theory (Signaling Theory)}

This theory was propounded by Michael Spence 1973, modified by Bhattacharya (1979), Miller and Rock (1985), and John and Williams (1985) pronounced that managers as insiders choose dividend payment levels and increases, to signal private information to investors. It has been observed both in practice and theory that dividend announcement influences the market and investors' decisions, managers always strive to develop a good policy in terms of dividend due to this effect. The change in dividend payment is to be interpreted as a signal to shareholders and investors about the future earnings prospects of the firm. Generally, a rise in dividend payment is viewed as a positive signal, conveying positive information about a firm's future earnings prospects resulting in an increase in share price. Conversely a reduction in dividend payment is viewed as negative signal about future earnings prospects, resulting in a decrease in share price and wealth of investors. The theorists therefore conclude that the dividend signaling hypothesis confirms that increased (decreased) cash dividends should experience positive (negative) price reactions. Dividend announcements signaling future profitability have also been established through empirical research (Baker, Powell, \& Veit, 2002). Most share price changes took place immediately following the announcement of a dividend, especially positive or negative dividend changes, through findings of empirical studies conducted by Aharony and Swary (1980), Asquith and Mullins (1983), and Kalay and Lowenstein (1985) as noted in Baker, et al., (2002). However, consistency in findings in respect of dividend signaling models, have not been achieved over the years. 
Studies conducted by DeAngelo and DeAngelo (2006) did not support the hypothesized association between dividend policies and future earnings. According to Frankfurter and Wood (2002), advocated of the signaling theories believe that corporate dividend policy is a cheaper medium of conveying private information to the markets than any other media forms. Frankfurter and Wood (2002) stated that the use of dividends as signals imply that alternative methods of signaling are not perfect substitutes. Bhattacharya (1979) asserted that dividend plan affects favorably the financial performance of a company. According to John and William (1985), and Miller and Rock (1985) opined that information action with a business and beyond the house shareholders may create a signaling role for dividends. They show that dividend payments communicate private information in a disclosing manner completely. However, Modigliani and Miller (1961) argued in several ways, they noticed a firm's top management has everything about the firms and strategy of the business and could easily forecast future earnings of the business enterprise. Because of this, information asymmetry leading shareholders to convert every move by the business enterprise as an indicator to future cash flow. Thus, dividends turn into an indication to a firm's future performance. Miller and Rock (1985) discussed that dividends indeed have a signaling role but there are dissipative costs that are participating, and they basically are the firm's investment decisions. According to Easterbrook (1984), dividend increase may be an ambiguous signal unless industry can distinguish between growing businesses and disinvesting firms. Therefore, investor's reactions to changes in dividend insurance policy do not at all mean that potential buyers choose dividend to retained earnings.

\section{Review of Related Studies}

Abu and Adebayo (2020) examined how share price of conglomerates firms listed in Nigeria is influenced by their dividend policy using multiple regression analysis; they discovered that share price is positively and significantly influenced by dividend yield while dividend payout ratio exerted insignificant negative effect on share price. Also, it was reported that earnings negatively impacted on share price and dividend policy was found to significantly influenced the share price of the conglomerates companies. Similarly, Aribaba, et al., (2017) reported a significant effect of dividend policy on changes in share price of listed companies in Nigeria although they found insignificant positive effect of earnings on changes in share price, insignificant negative effect of dividend yield and dividend per share on changes in share price while it was reported that dividend payout ratio positively and significantly influenced changes in share price.

Ubesie, et al., (2020) conducted a correlational and bi-directional casual analysis between dividend policy and financial performance of listed consumer goods producing firms in Nigeria and found that dividend per share positively associated with financial performance while dividend payout ratio is negative but insignificantly related with financial performance; also, no evidence of bi-directional relationship between dividend policy and financial performance of the studied firms.

Wajid, et al., (2014) adopted a regression analysis to examine the impact of dividend policy on shareholders' wealth in the textile sector of Pakistan using 50 sampled companies for a period of 11 years (2001-2010); it was revealed that dividend per share, dividend payout, earning per share, price earning, lagged value of market price and lagged value of price earning positively and significantly influenced market price per share. Similarly, studies conducted by Omoregie and Eromosele (2016); Ojeme, et al., (2015) on the effect of dividend policy on shareholders' wealth of listed Banks in Nigeria revealed that dividend per share and retained earnings have significant positive effect on shareholders' wealth while significant negative relationship exists between earnings per share and shareholders' wealth.

Ansar, Butt and Shah, (2015) conducted on the impact of dividend policy on shareholders' wealth of 30 companies listed on the floor of Karachi Stock Exchange in Pakistan, using the textile, cement and chemical sectors of the economy as sampled size of the study; and discovered that a strong relationship between shareholders wealth and dividend policy (retained earnings, dividend per share, return on equity, and lagged market price of share). In like manner, Ordu, Enekwe and Anyanwaokoro (2014) reported direct relationship between dividend per share, dividend yield and dividend payout ratio, and share prices of quoted firms in Nigeria using ordinary least squares techniques. Contrarily, Chenchene, and Mensah (2015) discovered insignificant effect of firm size, current dividend payout and current investment on shareholders 
wealth of UK retail industry from 2004-2008 while earnings, profitability, leverage, and lagged dividend payout directly influenced shareholders wealth. The overall result of the study of Chenchene, and Mensah (2015) indicated that dividend policy has positive effect on shareholders wealth.

Sijol and Basit (2016) examined the impact of dividend policy on shareholders' wealth in manufacturing industry of NASDAQ Stock Exchange, United States of America. The study employed data extracted from 300 companies for a period of 2011-2015 and found that dividend policy positively impacted on shareholders' wealth of the manufacturing companies sampled for the study. On the contrary, the studies of Dilawer (2012); Hashemijoo, Mahadavi-Ardekani and Younesi (2012) from Pakistan as well examined the relationship between share price and dividend policy from the Pakistan textile industry. The study found that there was a negative significant relationship between dividend policy and share price.

Zafar, Waseem and Asad (2014) examined the impact of dividend policy on shareholders' wealth in context of Pakistan using thirty-five companies selected from three sectors; Textile, Sugar and Chemical. The results of the OLS technique employed revealed that dividend policy, firm growth rate, and firm size have significant positive impact on shareholders' wealth. Hunjra, Ijah, Chani, Hassan and Mustafar (2014) examined the effect of dividend yield, dividend payout ratio, return on equity, earning per share and profit after tax on stock prices in Pakistan. The result of the Ordinary least square regression model applied showed that dividend payout ratio, profit after tax and earnings per share have significant positive impact on stock price have significant impact on stock price while dividend yield negatively related with stock price.

\section{METHODOLOGY}

The study employed an ex-post facto research design, the data used were secondary data extracted from the audited financial statements of the selected ten (10) companies for a period of ten (10) years from 2008 to 2017. The data of market share prices were derived from the Nigerian Stock Exchange database for the period under consideration were included. The study adopted multiple regression analysis (Pooled OLS) in determining the effect of the dividend policy on shareholders' wealth, with and without the control of return on assets with the aid of STATA IC/14. The choice of the estimating techniques was made based on the results of the Hausman test, heteroscedasticity test, cross dependence test and the serial correlation test carried out to ensure the suitability of the model for objective prediction.

This study examined the effect of dividend policy on shareholders' wealth of listed manufacturing companies in Nigeria controlling for return on assets. The models of the study is stated thus:

$$
\begin{aligned}
& \text { MPS }_{\text {it }}=\beta_{0}+\beta_{1} \mathrm{DPR}_{\mathrm{it}}+\beta_{2} \mathrm{DYD}_{\mathrm{it}}+\beta_{3} \mathrm{DPS}_{\mathrm{it}}+\varepsilon_{\mathrm{it}} \\
& \mathrm{MPS}_{\mathrm{it}}=\beta_{0}+\beta_{1} \mathrm{DPR}_{\mathrm{it}}+\beta_{2} \mathrm{DYD}_{\mathrm{it}}+\beta_{3} \mathrm{DPS}_{\mathrm{it}}+\beta_{4} \mathrm{ROA}_{\mathrm{it}}+\varepsilon_{\mathrm{it}}
\end{aligned}
$$

where: MPS: Market price per share; DPR: Dividend Payout Ratio; DVD: Dividend Yield; DPS: Dividend per Share; and ROA = Return on Assets. $\beta_{1}-\beta_{4}$ are the coefficients of the proxies of independent variables, "i" represent the number of companies while " $t$ " means number of periods covered. " $\varepsilon$ " represent the stochastic error in the models.

The purpose of the models was to determine whether there is any relationship between dividend policy and shareholders' wealth. The variables were selected on the basis of their relevancy to the model, and their importance in depicting shareholders confidence on the dividend policy being adopted towards enhancing their wealth. 
TABLE 1

SUMMARY OF MEASUREMENT AND JUSTIFICATIONS OF VARIABLES

\begin{tabular}{|c|c|c|c|}
\hline Variables & Abbreviation & Measurement & Justifications \\
\hline \multicolumn{4}{|l|}{ Dependent Variable } \\
\hline Market share price & MPS & $\begin{array}{l}\text { The stock exchange market share price } \\
\text { as at the end Financial year of firm. }\end{array}$ & $\begin{array}{l}\text { Aribaba, et al., } \\
(2017)\end{array}$ \\
\hline \multicolumn{4}{|c|}{ Independent Variables } \\
\hline Dividend Payout & DPR & $\mathrm{DPR}=\frac{\text { Total Dividend }}{\text { Equity ranking for Dividend }}$ & $\begin{array}{l}\text { Ubesie, et al., } \\
\text { (2020) }\end{array}$ \\
\hline Dividend Yield & DYD & $\mathrm{DYD}=\quad \frac{\mathrm{DPS}}{\mathrm{MPS}}$ & $\begin{array}{l}\text { Abu and } \\
\text { Adebayo (2020) }\end{array}$ \\
\hline Dividend per Share & DPS & $\begin{array}{l}\text { DPS }=\text { Ordinary Share dividend } \\
\text { Number of Ordinary Shares }\end{array}$ & $\begin{array}{l}\text { Aribaba, et al., } \\
\text { (2017) }\end{array}$ \\
\hline
\end{tabular}

Source: Compiled by the Author (2021)

\section{RESULTS AND DISCUSSIONS}

\section{Descriptive Analysis}

TABLE 2

DESCRIPTIVE STATISTICS

\begin{tabular}{|l|lllll|}
\hline VARIABLES & MPS & DPR & DYD & DPS & ROA \\
\hline Mean & 120.744 & 0.518 & 0.047 & 3.156 & 0.113 \\
Std. Dev. & 252.118 & 0.430 & 0.101 & 5.352 & 0.080 \\
Min & 2.270 & -2.388 & 0.000 & 0.000 & -0.060 \\
Max & 1555.990 & 1.394 & 0.992 & 29.000 & 0.319 \\
\hline
\end{tabular}

Source: Author's Computation (2021)

According to the result in the Table 2, there are 100 observations. The average value of the market price per share (MPS) is 120.74. This means that on the average, the value that was assigned to each share of the companies during the period of this study is N 120.74. The median value 35.4 and that of mean are not the same. This means that the variable is not symmetrical. The average value of Dividend Payout Ratio (DPR) is 0.518 . This value suggests that the proportion of the current period earnings or profit that was distributed as dividend to shareholders during the period of this study is $51.8 \%$.

The maximum value of 1.394 , minimum value of -2.388 and standard deviation of 0.430 indicate that there is a wide gap between the values. The wide gap between the DPR of the firms is also evident in different between the estimated mean and median (51.8\%). The average value of the Dividend Yield (DYD) as a ratio of Dividend per share to market price per share is 0.047 having the minimum to be 0.00 and the maximum value of 0.992 respectively. However, considering the measure of dispersion having a value of 0.101 and the median value of 0.029 it is safe to say that there is no wide gap between the sizes of the selected firms.

The Dividend per Share (DPS) hovers around N0.00 and N29.00. The average value of the variable is 3.156. This means that the average amount of dividend declared by the firms for every ordinary share outstanding during the period of this study is N3.17. Nevertheless, as evident in the standard deviation value of 5.352 and the median value of 0.950 it is safe to say that wide gap exists between the values of the 
variable. Furthermore, the skewness value of the series is 2.944 . The average value of the return on asset (ROA) is 0.113 . This means that on the average, the ratio of the selected firms' net income to total asset is $11.3 \%$. Alternatively, this means that during the period of this study, the firms are able to generate income to the tune of about $11.3 \%$ of the total asset.

\section{Correlation Matrix}

This section presents the results of preliminary correlation analyses among the variables. The correlation analysis was carried out to discover if there is existence of unhealthy multi-correlation among the independent variables and to ensure the suitability of the variables in the model for the analysis.

TABLE 3

\section{CORRELATION MATRIX}

\begin{tabular}{|l|l|l|l|l|}
\hline & DPR & DYD & DPS & ROA \\
\hline DPR & 1 & & & \\
\hline DYD & $0.2814 *(0.0046)$ & 1 & & \\
\hline DPS & $0.2623^{*}(0.0084)$ & $0.1431(0.1556)$ & 1 & \\
\hline ROA & $0.3848 *(0.0001)$ & $0.2082 *(0.0376)$ & $0.4754 *(0.0000)$ & 1 \\
\hline
\end{tabular}

Source: Author's Computation (2021)

The correlation result showed that the coefficients range between 0.1431 and 0.4754 . Explicitly, the result shows that positive and significant association exists between Dividend Yield (DYD) and Dividend Payout Ratio (DPR) $(r=0.2814$; P-value $=0.0046)$. The positive correlation is statistically significant at $1 \%$ level of significance. In similar way, a positive and significant correlation exists between Dividend per Share (DPS) and Dividend Payout Ratio (DPR) $(r=0.2623$; P-value $=0.0084)$. Similarly, a positive and significant correlation is found between Return on Asset (ROA) and Dividend Payout Ratio (DPR) $(r=$ 0.3848; P-value $=0.000$ ). A positive and insignificant correlation is seen between Dividend per Share (DPS) and Dividend Yield (DYD) $(\mathrm{r}=0.1431 ; \mathrm{P}$-value $=0.1556)$. However, a positive and significant correlation exists between Return on Asset (ROA) and Dividend Yield (DYD) $(r=0.2082$; P-value $=0.0376$ ). This association is similarly to the association between Return on Asset (ROA) and Dividend per Share (DPS) $(\mathrm{r}=0.4754$; P-value $=0.000)$. Overall, the study found that weak correlation is found among the Dividend Policy Indicators and the control variable which are to be used as independent variable in the next section of this chapter. Thus, we conclude that there is no possibility of having multicollinearity problem in our regression analysis.

TABLE 4

\section{REGRESSION RESULTS}

\begin{tabular}{|l|l|l|l|}
\hline \multicolumn{2}{|l|}{ VARIABLES } & Equation One & Equation Two \\
\hline \multirow{4}{*}{ DPR } & Coeff. & -16.90 & -12.77 \\
\cline { 2 - 4 } & Std. Error & 26.81 & 28.12 \\
\cline { 2 - 4 } & t-stat. & -0.63 & -0.45 \\
\cline { 2 - 4 } & P-value & 0.53 & 0.65 \\
\hline \multirow{5}{*}{ DYD } & Coeff. & $-559^{*}$ & $-553.5^{*}$ \\
\cline { 2 - 4 } & Std. Error & 112 & 112.6 \\
\cline { 2 - 4 } & t-stat. & -5.01 & -4.92 \\
\cline { 2 - 4 } & P-value & 0.000 & 0.00 \\
\hline \multirow{3}{*}{ DPS } & Coeff. & $0.433^{*}$ & $0.44^{*}$ \\
\cline { 2 - 4 } & Std. Error & 0.021 & 0.02 \\
\cline { 2 - 4 } & t-stat. & 20.69 & 19.31 \\
\hline
\end{tabular}




\begin{tabular}{|l|l|l|l|}
\hline & P-value & 0.000 & 0.00 \\
\hline \multirow{5}{*}{ ROA } & Coeff. & & -0.83 \\
\cline { 2 - 4 } & Std. Error & & 1.64 \\
\cline { 2 - 4 } & t-stat. & & -0.51 \\
\cline { 2 - 4 } & P-value & 19.24 & 0.613 \\
\hline \multirow{5}{*}{ Constant } & Coeff. & 17.14 & 24.78 \\
\cline { 2 - 4 } & Std. Error & 1.12 & 20.39 \\
\cline { 2 - 4 } & t-stat. & 0.265 & 1.22 \\
\cline { 2 - 4 } & P-value & 100 & 0.23 \\
\hline Observations & 0.8249 & 100 \\
\hline Adj. R-squared & $\mathrm{F}_{(3,96)}=150.73[0.000]$ & 0.818 \\
\hline F-test [P-value] & $\mathrm{Chi}_{(4,95)}{ }_{(3)}=3.50[0.3203]$ & $\mathrm{Chi}^{2}(4)=5.73[0.22]$ \\
\hline Hausman [P-value] & $\mathrm{Chi}^{2}{ }_{(1)}=0.00[1.000]$ & $\mathrm{Chi}^{2}{ }_{(1)}=0.00[1.000]$ \\
\hline LM [P-value] & $\mathrm{Chi}^{2}{ }_{(1)}=299.75[0.000]$ & $\mathrm{Chi}_{(1)}{ }_{(1)}=300.77[0.000]$ \\
\hline Heteroskedasticity [P-value] & $\mathrm{F}_{(1,9)}=2022[0.000]$ & $\mathrm{F}_{(1,9)}=853.42[0.000]$ \\
\hline Autocorrelation [P-value] &
\end{tabular}

Source: Author's Computation (2021)

Table 4 presented the panel regression analysis that establish the relationship between Market Price per Share (MPS) and Dividend Policy indicators used with and without control variable in this study.

$M P S=19.24-16.9 D P R-559 D Y D+0.433 D P S$

The Hausman test values of $3.50(\mathrm{P}$-value $=0.3203)$ supported the appropriateness of the random effect. Probing further, the Breusch-Pagan LM test was carried out and the result with $\rho$-value of 1.000 negates the report of Hausman test, thus the study concluded that Pooled OLS is the best estimating option for Model One. The diagnostic test carried out revealed that the model has both heteroskedasticity and serial auto correlation problem and thus, the model was estimated using Polled OLS with cluster errors.

The Beta revealed the direction and magnitude of the effect of each of the independent variable parameters on the dependent variable, while the probability of the T-statistics showed the significant impact. From the results presented in Table 4, dividend payout ratio (DPR) has negative but insignificant effect on market price per share (MPS) $(\beta=-16.90, \rho$-value $=0.53)$, dividend yield (DYD) exerted substantial and significant negative effect on MPS $(\beta=-559, \rho$-value $=0.00)$. Contrarily, dividend per share (DPS) exhibited a positive and significant effect on MPS $(\beta=0.433, \rho$-value $=0.00)$. The result of the coefficients of the individual independent variables revealed that a unit increase in DYD would result to 559 kobo decline in MPS while a kobo increase in DPS would lead to $0.433 \mathrm{kobo}$ increase in MPS. The probability of the F-statistic denotes the significance of the joint effect of all the independent variable when combined, the $\rho$-value of 0.00 implies that dividend policy measured as Dividend Payout Ratio (DPR), Dividend Yield (DYD), Dividend Per Share (DPS) jointly and significantly affect MPS of manufacturing companies listed in Nigeria. The coefficients of multiple determination (Adjusted $\mathrm{R}^{2}$ ) of 0.8249 means that $82.49 \%$ variations in the MPS resulted from the combined changes in Dividend Payout Ratio (DPR), Dividend Yield (DYD), Dividend Per Share (DPS) respectively, while the remaining $17.51 \%$ variations in market price per share is led by other factors or variables not captured in model One.

Based on the probability of the F-statistics of 0.000 , being significant, this study therefore rejects the null hypothesis one which states that dividend policy does not significantly affects market price per share of listed manufacturing companies in Nigeria. The alternate hypothesis indicating that dividend policy has significant effect on market price per share is hereby accepted.

The insignificant relationship between dividend payout ratio and market price per share as obtained in this study contradicts the reports of study conducted in Pakistan by Wajid, et al., (2014) which discovered that dividend payout has a significant impact at five percent on market price per share. Likewise, the report 
of Chenchene, and Mensah (2015) which found that a year lagged dividend payout ratio has significant effect on shareholders wealth in their study on the effect of dividend policy on shareholders wealth in the UK retail industry from 2004-2008 using 25 firms from the retail industry in the UK were selected.

While, the significant positive effect of dividend per share of this study aligned with the findings of: Wajid, et al., (2014) who reported that dividend per share has a significant positive impact on market price per share of Pakistan textile firms; Omoregie and Eromosele (2016), Ojeme et al., (2015) who found that significant positive relationship exists between Dividend per Share (DPS) and Shareholders' wealth of Banks in Nigeria for a period ranging from 2010 - 2014. Similar result was obtained in the study of Ordu, et al., (2014) in their study on the effect of dividend payment on the market prices of shares of quoted firms in Nigeria using 17 quoted firms.

It was obtained that dividend yield significantly impacted on market price per share in a negative direction; this result is consistent with the findings of Aribaba, et al., (2017); Hunjra, et al., (2014) who found that dividend yield has a negative relationship with share prices

The result of the multiple regression showed that dividend policy significantly influences market price per share of manufacturing companies listed in Nigeria. This finding is consistent with the reports of Wajid, et al., (2014), Zafar, et al., (2014) but negates the reports of Dilawer (2012); and Hashemijoo, et al., (2012) from Pakistan who obtained a significant negative relationship between dividend policy and share price. The contrast in the result could result from the measures adopted by various scholars for dividend policy, the time frame and the difference in the geographical coverage of the studies reviewed.

Equation Two was established by introducing return on assets (ROA) as control variable to Model One in order to examine if ROA controls the relationship between dividend policy and market price per share of manufacturing companies listed in Nigeria.

$M P S=24.78-12.77 D P R-553.5 D Y D+0.44 D P S-0.83 R O A$

The $\rho$-value of Hausman test conducted of 0.22 supported the appropriateness of the random effect. While the result of the Breusch-Pagan LM test carried out with $\rho$-value of 1.000 negates the report of Hausman test, thus the study concluded that Pooled OLS is the best estimating option for Equation Two. The diagnostic test carried out revealed that the model has both heteroskedasticity and serial auto correlation problem and thus, the model was estimated using Pooled OLS with cluster errors.

The Beta revealed the direction and magnitude of the effect of each of the independent variable parameters on the dependent variable, while the probability of the T-statistics showed the significant impact. From the results presented in Table 4, dividend payout ratio (DPR) has negative but insignificant effect on market price per share (MPS) $(\beta=-12.77, \rho$-value $=0.65)$, dividend yield (DYD) exerted substantial and significant negative effect on MPS $(\beta=-553.5, \rho$-value $=0.00)$. Contrarily, dividend per share (DPS) exhibited a positive and significant effect on MPS $(\beta=0.44, \rho$-value $=0.00)$ while return on asset (ROA) impacted market price per share negatively but insignificantly $((\beta=-0.83, \rho$-value $=0.613)$. The result of the coefficients of the individual independent variables revealed that a unit increase in DYD would result to 553.5kobo decline in MPS while a kobo increase in DPS would lead to 0.44 kobo increase in MPS. The probability of the F-statistic denotes the significance of the joint effect of all the independent variable when combined, the $\rho$-value of 0.00 implies that dividend policy measured as Dividend Payout Ratio (DPR), Dividend Yield (DYD), Dividend Per Share (DPS) jointly and significantly affect MPS of manufacturing companies listed in Nigeria. The coefficients of multiple determination (Adjusted $\mathrm{R}^{2}$ ) of 0.818 means that $81.8 \%$ variations in the MPS resulted from the combined changes in Dividend Payout Ratio (DPR), Dividend Yield (DYD), Dividend Per Share (DPS) with the control effect of return on asset (ROA) respectively, while the remaining $18.1 \%$ variations in market price per share is led by other factors or variables not captured in Equation Two.

Based on the probability of the F-statistics of 0.000 , being significant, this study therefore rejects the null hypothesis one which states that return on asset does not significantly control the relationship between dividend policy and market price per share of listed manufacturing companies in Nigeria. The alternate 
hypothesis indicating that return on asset significantly control the relationship between dividend policy and market price per share is hereby accepted.

The results obtained in Model Two are consistent with the findings of Model One except for the introduction of control variable (ROA). From the result of the regression analysis presented in Table 4, it was observed that ROA has insignificant negative effect on market price per share. Also, comparing the values of the coefficient of multiple determinations of Model One with Model Two, that is 0.8249 and 0.818 ; there is a reflection that the introduction of ROA led to slight decrease in the joint effect of the model. The combined effect of the explanatory powers of the independent variable together with that of control variable (ROA) dragged the adjusted $\mathrm{R}^{2}$ from 0.8249 to 0.818 ; this implies that introduction of ROA as control variable weakened the powers of the joint variables and result to decline in its causal variations.

The findings of the study aligned with the underlying theory; that is, signaling theory. It is evidenced that dividend policy significantly impacted on all the three measures of shareholders' wealth (market price per share, shareholders' fund, and price earnings ratio). This supported the assertion of signaling theory which posited that managers use dividend to bridge information asymmetry between the owners of the firm and the management. Also, dividend sent information of good performance of the companies' operation to the market, thus enhances the shareholders' wealth.

\section{CONCLUSION}

This study examined the effect of dividend policy on shareholders" wealth. It also established the control effect of return on assets on the relationship between the chosen dividend policy measures of dividend payout ratio (DPR), dividend yield (DVD) and dividend per share (DPS) on shareholders' wealth. The results obtained indicated that all the dividend policy proxies are jointly significant in influencing shareholders' wealth. Also, the significant influence becomes more obvious when the control variable of return on assets was introduced. Therefore, the six null hypotheses were rejected. Considering the findings and conclusion of this study, the following recommendations are made which may be useful to the management, shareholders, market analysts, policy makers and other stakeholders: In this study, using the dividend payout (DPR), dividend yield (DYD) and dividend per share (DPS) models, managers and shareholders should pay more attention to the companies operational needs by understanding the relationship between profit maximization and dividend policies, because policies on dividend cannot hold if there is no distributable profits.

The study is of the opinion that managers should ensure shareholders' wealth increase and growth, by ensuring there is continuous, stable and quality dividend payment at the end of each trading period, since the results from the study revealed a strong positive effect of dividend per share on all shareholders' wealth virtually on the models used. Shareholders, policy makers and stakeholders should create appropriate business operating framework to enable managerial effectiveness for wealth creation, because, where there is no conducive business operating environment, it becomes difficult to create value and implement any dividend policy.

\section{REFERENCES}

Abu, S.O., \& Adebayo, E. (2020). Effect of dividend policy on share price of listed conglomerate firms in Nigeria. African Journal of Management Research, 26(2019), 39-56.

Adediran, S.A., \& Alade, S.O. (2013). Dividend policy and corporate performance in Nigeria. American Journal of Social and Management Sciences, 4(2), 71-77.

Aharony, J., \& Swary, I. (1980). Quarterly dividend and earnings announcements and stockholders' returns: An empirical analysis. Journal of Finance, 35, 1-12.

Ajanthan, P., (2013). Impact of dividend policy on shareholder's wealth: an empirical analysis of Indian Information Technology Sector. Asia-Pacific Finance and Accounting Review, 1(3), 17-25.

Akinleye, G.T., \& Ademiloye, D.S. (2018). Dividend policy and performance of quoted manufacturing firms in Nigeria. International Journal of Scientific \& Engineering Research, 9(7), 1769-1784. 
Akinsulire, O. (2016). Financial management $\left(5^{\text {th }}\right.$ Ed). Mushin - Lagos Nigeria. El-Toda ventures ltd publishers.

Akit, F.M., Hamzah, N.H., \& Ahmad, N. (2015). Impact of dividend policy on the shareholders' wealth: Shariah vs Non-Shariah companies. Global Trend in Economic Research, 2(1), 722-743.

Ansar, I., Butt, A.A., \& Shah, S. B.H. (2015). Impact of dividend policy on shareholders' wealth International Review of Management and Business Research, 4(1), 89-95.

Araoye, F.E., \& Aruwaji, A.M. (2019). Effect of dividend policy on stock price volatility in Nigeria Stock Exchange. International Journal of Accounting and Financial Reporting, 9(2), 219-231.

Aribaba, F.O., Ahmodu, O.L., Ogbeide, S.O., \& Olaleye, J.O. (2017). Dividend policy and share price changes in the stock market: Evidence from Nigeria. Journal of Business and Organizational Development, 9(4), 30-47.

Asquith, P., \& Mullins, D.W., Jr. (1983). The impact of initiating dividend payments on shareholders' wealth. Journal of Business, 56, 77-96.

Baker, H.K., Powell, G.E., \& Veit, E.T. (2002a). Revisiting managerial perspectives on dividend policy. Journal of Economics and Finance, 26, 267-283.

Baker, H.K., Powell, G.E., \& Veit, E.T. (2002b). Revisiting the dividend puzzle: Do all of the pieces now fit? Review of Financial Economics, 11, 241-261.

Baker, H.R. (2015). Managerial finance: Dividends and Dividend Policy (2 ${ }^{\text {nd }}$ Ed). Emerald Group Publishing Limited. Finland.

Barman-Joshi, R. (2011). Effect of dividends on stock prices in Nepal. NRB Economic Review, 16(4), 2127.

Bhattacharya, S. (1979). Imperfect information, dividend policy, and the bird in the hand. fallacy. Bell Journal of Economics, 10(1), 259-270.

Biza-Khupe, S.A. (2016). The relationship between dividend payout and firm financial performance: A study of Botswana Listed Companies. Archives of Business Research, 2(2), 51-62.

Black, F., \& Scholes, M. (1976). The effects of dividend yield and dividend policy on common stock prices and returns. Journal of Financial Economics, 1(1), 1-22.

Chaabouni, I. (2017). Impact of dividend announcement on stock return: A study on listed companies in the Saudi Arabia financial markets. International Journal of Information, Business and Management, 9(1), 37.

Chauhan, J., Ansari, M.S., Taqi, M., \& Ajmal, M. (2019). Dividend policy and its impact on performance of Indian information technology companies. International Journal of Finance and Accounting, $8(1), 36-42$.

Chenchene, J., \& Mensah, K. (2015). Dividend policy and its effects on shareholders wealth: Evidence from UK retail industry. International Journal of Liberal Arts and Social Science, 3(2), 52-64.

DeAngelo, H., \& DeAngelo L. (2006). The irrelevance of the mm dividend irrelevance theorem. Journal of Financial Economics, 79(2), 293-31.

Dilawer, T. (2012). Earning management and dividend policy: evidence from Pakistani Textile Industry. International Journal of Academic Research in Business \& Social Sciences, 2(10), 45-58.

Easterbrook, F.H. (1984). Two Agency costs explanations of dividends. American Economic Review, 74, 650-659.

Ebire, K., Sadiq, M.S., \& Onmonya, L. (2019). Effect of dividend policy on the performance of listed firms in Nigeria. International Journal of Scientific and Research Publications, 8(6), 289-302.

Erasmus, P. (2012). The influence of dividend yield and dividend stability on share return: Implications for dividend policy formulation. Journal of Economic and Financial Sciences, 6(1), 13-32.

Fernandez, P. (2015). Valuation methods and shareholder value creation ( $2^{\text {nd }}$ Ed.). Academic Press, NY.

Frankfurter, G.M., \& Wood, B.G., Jr. (2002). Dividend policy theories and their empirical tests. International Review of Financial Analysis, 11, 111-138.

Gordon J.M. (1956). Dividends, earnings, and stock prices. Review of Economics and Statistics, 2(1), 85102. 
Grant-Baker, H.G.P. (2016). How corporate managers view dividend policy. Quarterly Journal of Business and Economics, 2(1), 56-68.

Hashemijoo, M., Ardekani, A.M. \& Younesi, N. (2012). The impact of dividend policy on Share price volatility in the Malaysian Stock Market. Journal of Business, 4(1), 111-129.

Hunjra, A.I., Ijah, M.S., Chani, M.I., Hassan, S., \& Mustafa, U. (2014). Impact of dividend policy, earning per share, return on equity, profit after tax on stock prices. International Journal of Economics and Empirical Research, 2(3), 109-115.

Idewele, I.O., \& Murad, B. (2019). Dividend policy and financial performance: A study of selected deposit money banks in Nigeria. African Journal of Business Management, 13(7), 239-255.

Irtaz, M., Arslan, G., \& Syed, Y. (2018). Impact of capital structure on financial performance and shareholder wealth. International Journal of Learning \& Development, 4(2), 27-33.

John, K., \& Williams, J. (1985). Dividends, dilution, and taxes: A signaling equilibrium. Journal of Finance, 40, 1053-1070.

Kalay, A., \& Loewenstein, U. (1985). Predictable events and excess returns: The case of dividend announcements. Journal of Financial Economics, 14, 423-449.

Kibet, B., Tenai, J., Cheruiyot, T., Maru, L., \& Kipsat, M. (2010). The Level of corporate dividend payout to Stockholders: Does optimal dividend policy exist for firms quoted at the Nairobi Stock Exchange? International Business \& Economics Research Journal, 9(3), 71-84.

Kolawole, E., Sadiq, M.S., \& Lucky, O. (2018). Effect of dividend policy on the performance of listed oil and gas firms in Nigeria. International Journal of Scientific and Research Publications, 8(6), $12-$ 35.

Lintner, J., (1956). Distribution of incomes of corporations among dividends, retained earnings, and taxes. American Economic Review, 46, 97-113.

Liu, L. (2018). The influence of corporate social responsibilities and the quality of financial statements. Asian Journal of Finance \& Accounting, 1(1), 52-71.

Miller, M.H., \& Rock, K. (1985). Dividend policy under asymmetric information. Journal of Finance, 40, 1031-1051.

Modigliani, F., \& Miller, M.H. (1961). Dividend policy, growth, and the valuation of shares. American Economic Review, 48(3), 261-297.

Modigliani, F., Franco, H., Merton, H., \& Miller, H. (1958). The cost of capital, Corporation Finance and the theory of Investment. American Economic Review, 3(48), 261-297.

Monogbe-Tunde, G.I.A. (2015). Dividend policy on financial performance: A case study of selected registered firm in Nigeria. Research Journal of Finance and Accounting, 2(2), 41-53.

Morara, G.O. (2015). The influence of dividends policy on market share prices at the Nairobi Securities Exchange. Asian Research Journal of Business Management, 1(3), 22-39.

Nazrul, M.M.I. (2019). Effects of dividend on stock price: A case of fuel and power industries in Bangladesh. International Journal of Accounting and Financial Reporting, 9(2), 87-98.

Nyor, T., \& Nasiru, R. (2015). Association between accounting numbers and value of food and beverages firm in Nigeria. International Journal of Economics and Finance, 7(12), 40-58.

Odesa, J.O., \& Ekezie, A. (2015). Determinants of dividend policy in quoted companies in Nigeria. African and Global Perspectives, 1(1), 1-13.

Ojeme, S., Mamidu, A.I., \& Ojo, J.A. (2015). Dividend policy and shareholders' wealth in Nigerian quoted banks. Canadian Social Science, 11(1), 24-29.

Omoregie, A.E., \& Eromosele, P.E. (2016). Dividend policy and shareholders' wealth: Evidence from some quoted banks. International Journal of Marketing \& Financial Management, 4(6), 55-72.

Ordu, M.M., Enekwe, C.I., \& Anyanwaokoro, M. (2014). Effect of dividend payment on the market price of shares: A study of quoted firms in Nigeria. Journal of Economics and Finance, 5(4), 49-62.

Ozuomba, C.N., Okaro, S.C., \& Okoye, P.V.C. (2013). Shareholder's value and firm's dividend policy: Evidence from public companies in Nigeria. Research Journal of Management Sciences, 2(12), 26-28. 
Priya, K., \& Nimalathasan, B. (2013). Dividend policy ratios and firm performance: A case study of selected hotels \& restaurants in Sri Lanka. Global Journal of Commerce and Management, 2(6), 16-22.

Rafindadi, A.A., \& Bello, A. (2019). Is dividend payment of any influence to corporate performance in Nigeria? Empirical evidence from panel cointegration. International Journal of Economics and Financial Issues, 9(2), 48-58.

Rampershad, A., \& De Villiers, C. (2018). The Association between dividends and accruals Quality. Australian Accounting Review, 1(2), 125-138.

Sarwar, M.S. (2013). Effect of dividend policy on shareholders' Wealth: A study of Sugar industry in Pakistan. Global Journal of Management and Business Research Finance, 13(7), 47-54.

Sijol, N.F., \& Basit, A. (2016). Impact of dividend policy on shareholder's wealth: A study on manufacturing industry listed in NASDAQ. America. International Journal of Accounting \& Business Management, 4(2).

Spence, M. (1973). Job Market Signaling. The Quarterly Journal of Economics, 87(3), 355-374.

Ubesie, M.C., Emejulu, C.E., \& Iyidiobi, F.C. (2020). Effect of dividend policy on financial performance of consumer goods manufacturing firms in Nigeria. Science Journal of Business and Management, 8(1), 7-15. doi: 10.11648/j.sjbm.20200801.12

Uzoaga, W.O., \& Alozie, U. (1998). Dividend policy in an era of indigenization. The Nigerian Journal of Economic and Social Studies, 16(1), 461-478.

Wajid, A., Arshad, A., Nazim, A., Bakhtiar, K.K., \& Qureshi, M.I. (2014). Impact of Dividend Policy on Shareholder Wealth in Pakistan (Evidence Textile Industry Perspective). Gomal University Journal of Research, 30(1), 58-69.

Zafar, I., Waseem, M.A., \& Asad, M. (2014). Impact of dividend policy on shareholders' wealth: A study of selected manufacturing industries of Pakistan International. Journal of Innovation and Applied Studies, 6(2), 210-215. 